Moses Stephen Pandu Prawira, Diah Ayu Candraningrum: Karakteristik Populisme Gubernur Jawa Barat (Ridwan Kamil) dalam Postingan Instagram 27 Mei 2018 - 27 Juni 2018

\title{
Karakteristik Populisme Gubernur Jawa Barat (Ridwan Kamil) dalam Postingan Instagram 27 Mei 2018 - 27 Juni 2018
}

\author{
Moses Stephen Pandu Prawira, Diah Ayu Candraningrum \\ moses.915160132@stu.untar.ac.id,diahc@fikom.untar.ac.id
}

Fakultas Ilmu Komunikasi Universitas Tarumanagara

\begin{abstract}
Populism is a phenomenon of political communication that can be a political strategy for politicians who want to represent themselves. During the campaign period for the Election of West Java Governor Ridwan Kamil as a candidate for governor used a populist strategy to gain political support from the people of West Java. Populism strategy is very important in democracy, Ridwan Kamil including pemimpin with a populist style. The characteristics of Ridwan Kamil's populism can be found in the form of Instagram posts, starting from May 27, 2018 - June 27, 2018 during the West Java Governor Election campaign period Ridwan Kamil gave Instagram posts that matched 9 characteristics of populism. Although it can get an influence on followers, populism can create fanatical effects. To find out the characteristics of Ridwan Kamil's populism on Instagram using data collection methods by taking interview data from Mr. Khalid Zabidi Golkar Party cadre, Ridwan Kamil's direct observation of Instagram, literature studies to support research and document studies.
\end{abstract}

Keywords: political communication, populism, ridwan kamil

\begin{abstract}
Abstrak
Populisme merupakan fenomena komunikasi politik yang dapat menjadi strategi politik bagi politikus yang ingin merepresentasikan dirinya. Dalam masa kampanye Pemilihan Gubernur Jawa Barat Ridwan Kamil sebagai calon gubernur menggunakan strategi populis untuk mendapatkan dukungan politik dari masyarakat Jawa Barat. Strategi populisme sangat penting dalam demokrasi, Ridwan Kamil termasuk pemimpin dengan gaya populis. Karakteristik populisme Ridwan Kamil bisa ditemui dalam bentuk postingan Instagram,Terhitung dari 27 Mei 2018 - 27 Juni 2018 saat masa kampanye Pemilihan Gubernur Jawa Barat Ridwan Kamil memberikan postingan Instagram yang sesuai dengan 9 karakteristik populisme. Meskipun dapat mendapatkan mempengaruhi pengikut, populisme dapat menciptakan efek fanatik Untuk mengetahui karakteristik populisme Ridwan Kamil di Instagram menggunakan cara pengumpulan data dengan mengambil data wawancara Bapak Khalid Zabidi Kader Partai Golkar, observasi langsung Instagram Ridwan Kamil, studi pustaka untuk mendukung penelitian dan studi dokumen.
\end{abstract}

Kata Kunci: komunikasi politik, populisme, ridwan kamil 


\section{Pendahuluan}

Secara sederhana, komunikasi politik (political communication ) merupakan salah satu dari fungsi input sistem politik yang menyebabkan bekerjanya semua fungsi dalam sistem politik. Komunikasi politik mengalirkan pesan-pesan politik berupa tuntutan, protes, dan dukungan (aspirasi dan kepentingan) ke pusat pemrosesan sistem politik dan hasil pemrosesan itu yang tersimpul dalam fungsi output dialirkan kembali oleh komunikasi politik yang menjadi feedback sistem politik (Paramita 2014:5).

Politisi didorong untuk berbicara dengan cara yang lebih populer dan meminta dukungan rakyat dengan lebih tekun. Organisasi media didorong untuk mencari cara untuk membuat politik lebih baik dan diterima oleh rakyat. Dengan cara memadukan informasi dan hiburan untuk mempopulerkan politik.

Populisme adalah fenomena komunikasi politik dimana para pemimpin populis menggunakan media sosial untuk menunjukan sifat populismenya. populisme menjadi sentral mengingat bahwa dalam beberapa tahun terakhir dukungan pemilihan diperoleh oleh partai dan pemimpin yang ditandai dengan referensi populis (Bracciale \& Martella 2017:1).

Secara sejarah, populisme mulai berkembang di Amerika Serikat melalui Aliansi Petani dan Partai Rakyat lalu di Rusia ada kelompok Narodniki yang anggotanya adalah kalangan intelektual yang menginginkan petani Rusia dan wilayah pedesaan sebagai model negara secara keseluruhan. Gerakan-gerakan populisme awal ini selalu memiliki hubungan dengan petani, sehingga populisme kerap disandingkan dengan gerakan agraria, revolusi reaksioner dan kelompok terbelakang di era modernisasi.

Ridwan Kamil hadir sebagai pemimpin yang populis di kota Bandung beberapa kebijakannya berupa penataan Kota Bandung, misalnya implementasi konsep Kota Teknopolis, Program Inovasi Pembangunan Pemberdayaan Kewilayahan (PIPPK), dan pembuatan Satuan Tugas (Satgas) khusus untuk menangani masalah prostitusi di Kota Bandung (Rahma 2019:3).

Fenomena ini menarik untuk diteliti karena Persatuan Bangsa-Bangsa (PBB) menilai Ridwan Kamil sebagai Gubernur yang efektif dalam mengambil kebijakan di masa pandemic coronavirus

Maka dari itu peneliti ingin menganalisis karakteristik populisme Ridwan Kamil dalam postingan instagram. Tangal yang dipilih oleh peneliti merupakan masa kampanye saat pemilihan Gubernur Jawa Barat dengan begitu, peneliti mengangkat judul: Karakteristik Populisme Ridwan Kamil Dalam Postingan Instagram 27 Mei 2018 - 27 Juni 2018. Berdasarkan konteks masalah yang telah diuraikan diatas, maka rumusan masalah penelitian adalah :

1. Apa saja karakteristik populisme Ridwan Kamil di postingan Instagram?

2. Apa dampak populisme dalam postingan Instagram Ridwan Kamil? 
Moses Stephen Pandu Prawira, Diah Ayu Candraningrum: Karakteristik Populisme Gubernur Jawa Barat (Ridwan Kamil) dalam Postingan Instagram 27 Mei 2018 - 27 Juni 2018

\section{Metode Penelitian}

Penulis menggunakan pendekatan penelitian kualitatif secara deskriptif. Penelitian yang dilakukan penulis bertujuan untuk mengetahui karakteristik populisme kepala daerah dalam postingan Instagram.

Menurut (Gunawan 2013:2) mendefinisikan penelitian kualitatif sebagai penelitian yang bermaksud untuk memahami fenomena tentang apa yang dialami oleh subjek penelitian yang mengutamakan penghayatan. Metode kualitatif adalah jenis penelitian yang temu-temunya tidak diperoleh melalu prosedur statistic atau bentuk hitungan. Melainkan penelitian kualitatif berusaha memahami dan menafsirkan makna suatu peristiwa interaksi tingkah laku manusia dalam situasi tertentu menurut pandangan peneliti tersebut (Gunawan 2013:2).

Istilah fenomenologi secara etimologis berasal dari bahasa Yunani. Dari akar kata "fenomenan" atau "fenomenon" yang secara harfiah berarti "gejala" atau "apa yang telah menampakkan diri" sehingga nyata bagi kita. Menurut Schutz, fenomenologi sebagai metode dirumuskan sebagai media untuk memeriksa dan menganalisis kehidupan batiniah individu yang berupa pengalaman mengenai fenomena atau penampakan sebagaimana adanya, yang lazim disebut arus kesadaran Fenomenologi merupakan salah satu jenis metode penelitian kualitatif yang diaplikasikan untuk mengungkap kesamaan makna yang menjadi esensi dari suatu konsep atau fenomena yang secara sadar dan individual dialami oleh sekelompok individu dalam hidupnya. Dengan demikian, studi dengan fenomenologi berupaya untuk mendeskripsikan makna pengalaman hidup banyak orang tentang suatu konsep atau gejala (Adian 2016).

Objek penelitian merupakan hal yang menjadi fokus dari suatu penelitian (Moleong 2018:132). Berdasarkan penelitian yang penulis angkat maka objek penelitian ini adalah Postingan Instagram Ridwan Kamil. Subjek penelitian sebagai benda, hal atau orang tempat data untuk variabel penelitian melekat dan yang di permasalahannya (Arikunto 2016:26). Subjek dalam penelitian ini adalah karakteristik populisme.

\section{Metode Pengumpulan Data}

Dalam penelitian ini data-data yang diperlukan penulis diperoleh berdasarkan metode pengumpulan data dengan cara sebagai berikut:

\section{Observasi}

Observasi adalah pengamatan terhadap objek yang diteliti baik secara langsung maupun tidak langsung. Kegiatan observasi digunakan hanya untuk mengamati pola perilaku manusia pada situasi tertentu untuk mendapatkan informasi tentang fenomena yang menarik (Agustinova 2015:36-37).

Observasi dapat dibedakan menjadi observasi partisipan dan observasi nonpartisipan. Observasi partisipan peneliti terlibat dengan kegiatan sehari-hari terhadap sumber yang sedang diamati untuk penelitian. Sedangkan observasi non-partisipan peneliti tidak terlibat dan hanya sebagai pengamat independen.

Penelitian ini menggunakan metode pengumpulan data observasi non partisipan. Pada observasi non partisipan penulis mengamati dan 
mendeskripsikan komunikasi populisme Ridwan Kamil dalam postingan instagram.

\section{Wawancara}

Wawancara adalah percakapan dengan maksud tertentu. Percakapan itu dilakukan oleh dua pihak yaitu pewawancara yang mengajukan pertanyaan dan terwawancara yang memberikan jawaban atas pertanyaan itu (Moleong 2018: 186).

Wawancara semi terstruktur merupakan jenis wawancara yang dilakukan dengan mempersiapkan beberapa pertanyaan namun dapat menyesuaikan pertanyaan selama proses wawancara berlangsung (Manzilati 2017: 70).

Pengumpulan data pada penelitian kualitatif ini penulis melakukan wawancara semi terstruktur dengan sistem mempersiapkan pertanyaan namun dapat menyesuaikan saat wawancara. Wawancara akan dilakukan terkait tentang karakteristik populisme Ridwan Kamil dalam postingan Instagram dengan narasumber yang mengetahui secara rinci dan jelas untuk menunjang penelitian ini.

A. Informan Kunci (key informan) Bapak Khalid Zabidi berusia 46 tahun anggota kader partai Golongan Karya (Golkar), Ketua Dewan Pimpinan Pusat Angkatan Muda Pembaharuan Indonesia (DPP AMPI) bagian kajian kebijakan dan strategi, Ketua Lembaga Pengembangan Wilayah Gerakan Pemuda Ansor (2011-2016).

B. Informan tambahan Bapak Ryan Marcelino berusia 25 tahun yang merupakan seorang Koki di salah satu rumah makan di jakarta sudah mengikuti Instagram Ridwan Kamil sejak 2017. Selama kuliah di Bandung Ia sangat senang dengan kinerja Ridwan Kamil yang efektif dalam menentukan kebijakan.

C. Informan tambahan Bapak Richard Anthony Pria 23 tahun asal Bandung yang sedang melanjutkan studi di kota Sydney beranggapan, bahwa sosok Ridwan Kamil adalah sosok yang penuh dengan pencitraan. Walaupun Ridwan Kamil sering memberikan postingan yang jenaka ia mengagangap bahwa hal tersebut memiliki efek buruk bagi Ridwan Kamil.

\section{Studi Pustaka}

Studi pustaka adalah aktivitas memperdalam dan mempelajari teori-teori dan konsep dari sejumlah literatur baik buku, jurnal, majalah, koran atau karya tulis lainnya yang relevan dengan topik, fokus atau variabel penelitian (Widodo 2017:75).

Peneliti memanfaatkan buku serta jurnal sebagai referensi yang berkaitan dengan teori populisme. Metode studi pustaka ini membantu penulis untuk memperoleh teori-teori serta informasi yang dibutuhkan melalui buku untuk menguatkan penelitian peneliti. 
Moses Stephen Pandu Prawira, Diah Ayu Candraningrum: Karakteristik Populisme Gubernur Jawa Barat (Ridwan Kamil) dalam Postingan Instagram 27 Mei 2018 - 27 Juni 2018

\section{Studi Dokumen}

Mendefinisikan studi dokumen merupakan pelengkap dari penggunaan metode observasi dan wawancara dalam penelitian kualitatif untuk mendapatkan hasil penelitian yang lebih kredibel atau dapat dipercaya (Agustinova 2015: 39).

Aktivitas dalam analisis data kualitatif dilakukan secara interaktif dan berlangsung secara terus menerus sampai tuntas. Analisis data kualitatif terdapat tiga tahap (Agustinova 2015:63-68).

\section{Hasil Temuan dan Diskusi}

Postingan Ridwan Kamil di Instagram secara umum sangat informatif dan menarik untuk dibaca ia juga sering memberikan caption yang terkesan jenaka. Ridwan Kamil adalah pemimpin yang populer dengan isu-isu pembangunan seperti pembangunan banyak taman pada masa kepemimpinannya.

Ridwan Kamil merupakan pemimpin yang trendy atau trendsetter, dengan isu-isu yang trendy memudahkan anak muda untuk memahami isi postingan Ridwan Kamil di Instagram. Sebelum menjadi Gubernur Ridwan Kamil sudah memulai dengan postingan yang mencampur kegiatan pribadi dan kegiatan sebagai wali kota. sehingga terciptalah kesan yang lebih personal terhadap followers-nya. Namun setelah menjadi Gubernur Ridwan Kamil di nilai lebih sering memposting kinerja-kinerjanya sebagai seorang Gubernur.

Ridwan Kamil terpantau sering memposting foto dirinya dengan berbagai artis ibu kota. Dengan postingan Ridwan Kamil yang dianggap jenaka hal itu berhasil mempengaruhi followers-nya sehingga Ridwan Kamil berhasil membangun citra sebagai teman dan Kepala Daerah.

Populisme membutuhkan popularitas dan popularitas membutuhkan citra atau image. Ridwan Kamil ingin menunjukan bahwa Ia adalah seorang pemimpin yang modern dan mengikuti perkembangan jaman tetapi tetap dekat dengan masyarakat. Postingan Ridwan Kamil termasuk pemimpin yang ingin menunjukan sisi populisnya sehingga ada dampak negatif dari postingan Ridwan Kamil tersebut.

Pemimpin yang ingin dipilih harus populer dengan isu populisme walau isu populis tersebut belum tentu cara yang tepat dalam menjawab persoalan masyarakat. Pemimpin dengan isu populis membuat pengaruh yang kuat pada pengikutnya sehingga seakan-akan terkesan fanatik. Postingan Ridwan Kamil juga dinilai terlalu lucu sehingga dalam satu saat Ridwan Kamil kehilangan sisi wibawanya sebagai seorang pemimpin. Penggunaan Instagram dalam menunjukan sifat populisnya dinilai tepat karena pengguna Instagram lebih banyak anak-anak muda di perkotaan dibandingkan di desa karena daya support budget dan kapasitas kuota yang lebih memadai. 
Tabel 1. Karakteristik Populisme Ridwan Kamil di Instagram

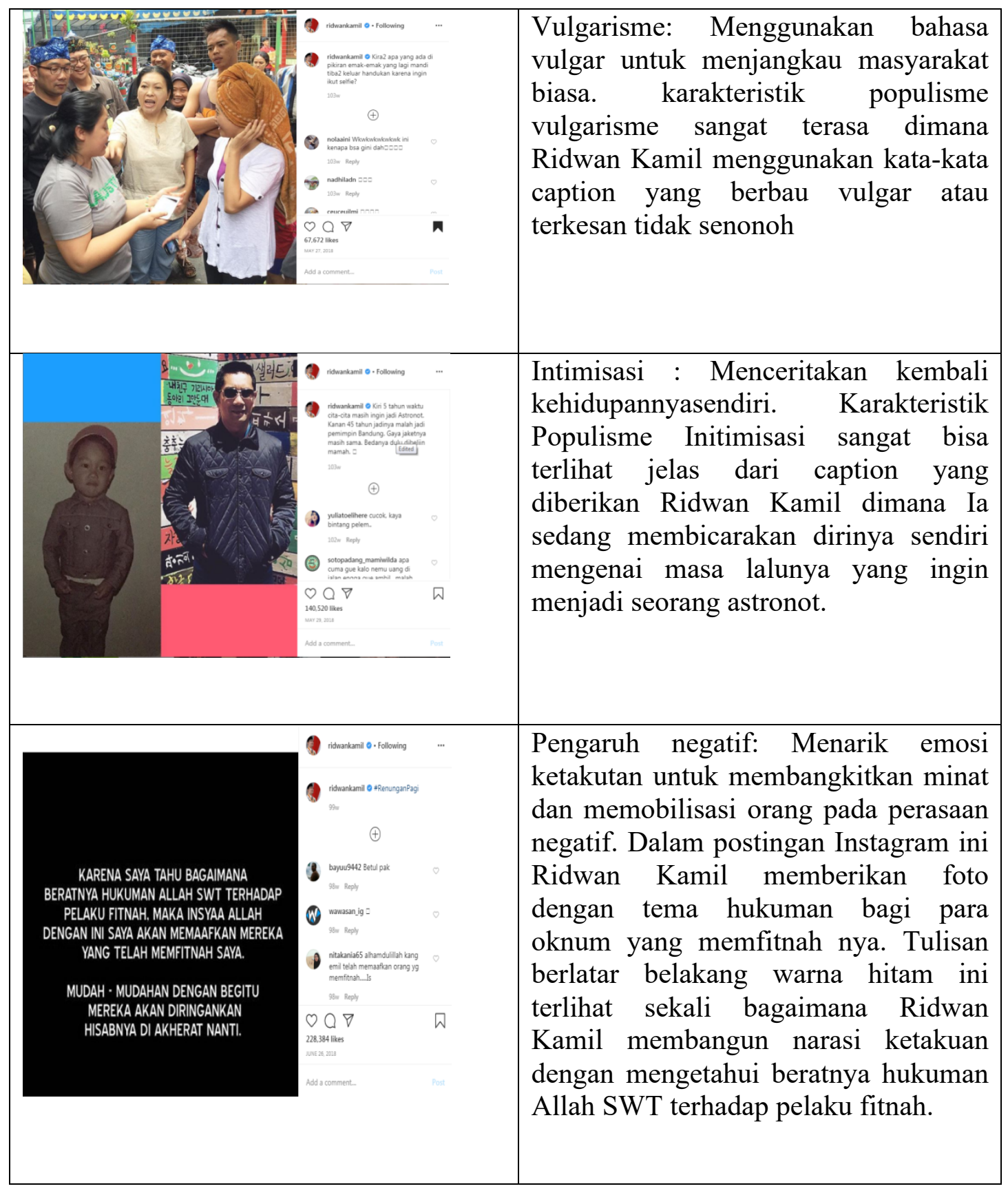




\begin{tabular}{|c|c|c|}
\hline & 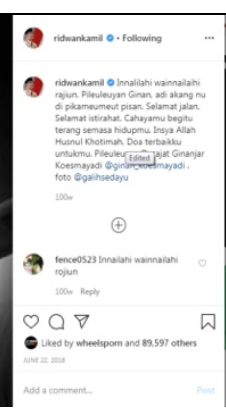 & $\begin{array}{l}\text { Emosionalisasi: Berbagi emosi atau } \\
\text { perasaan dengan terbuka. Dalam } \\
\text { postingan ini tedapat sosok sahabat } \\
\text { Ridwan Kamil dengan tampilan foto } \\
\text { hitam putih. Dengan mengunakan } \\
\text { tampilan hitam putih menunjukan } \\
\text { perasaan Ridwan Kamil yang sedang } \\
\text { berduka atas kepergian sahabatnya ini. }\end{array}$ \\
\hline & 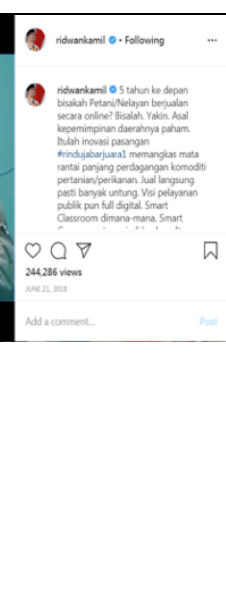 & $\begin{array}{l}\text { Penyederhanaan:Menyederhanakan } \\
\text { masalah dan solusi, menawarkan solusi } \\
\text { mudah untuk masalah yang kompleks. } \\
\text { Dalam postingan ini Ridwan Kamil } \\
\text { menunjukan foto dua orang yang } \\
\text { sedang memperhatikan televisi seakan- } \\
\text { akan orang tersebut sedang memberi } \\
\text { pelajaran atau memberi solusi ditambah } \\
\text { caption foto tersebut yang memberikan } \\
\text { solusi-solusi bagi petani dan nelayan } \\
\text { yang akan berjualan secara online } 5 \\
\text { tahun kedepan. }\end{array}$ \\
\hline 8 & $\underbrace{\infty}$ & $\begin{array}{l}\text { Bercerita: Menceritakan politik dengan } \\
\text { cara yang kaya dengan sindiran, } \\
\text { permainan kata-kata dan retorika. } \\
\text { Dalam postingan ini Ridwan Kamil } \\
\text { membagikan foto buku di dekat } \\
\text { Ka'Bah. Ridwan Kamil bermain } \\
\text { dengan kata-kata untuk bercerita } \\
\text { tentang masifnya fitnah yang } \\
\text { didapatkanya pada masa kampanye } \\
\text { Pemilihan Gubernur Jawa Barat } 2018 \text {. }\end{array}$ \\
\hline$=$ & 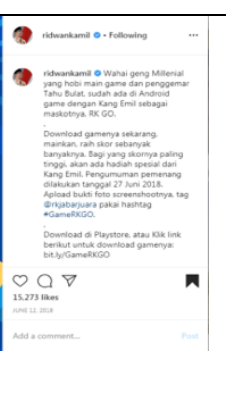 & $\begin{array}{l}\text { Informalitas: Berisi informasi yang } \\
\text { mengadopsi gaya langsung, sederhana, } \\
\text { non-formal dan non-institusional. } \\
\text { Dalam postingan ini Ridwan Kamil } \\
\text { memberikan gambar tentang } \\
\text { peluncuran game baru. Ridwan Kamil } \\
\text { juga memberikan informasi tempat } \\
\text { mengunduh game tersebut. }\end{array}$ \\
\hline
\end{tabular}




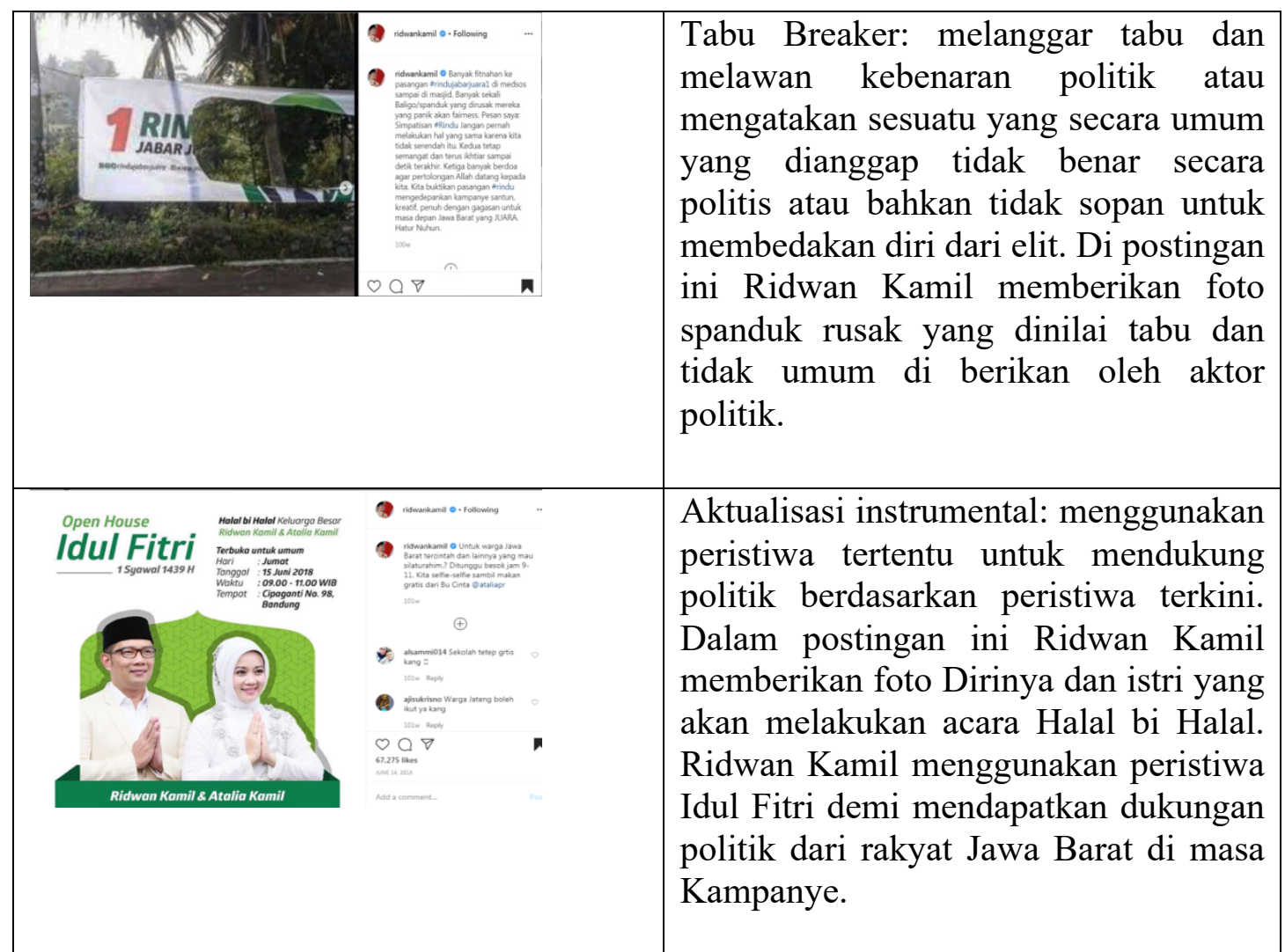

Komunikasi politik merupakan salah satu dari kegiatan politik yang memiliki tujuan untuk menyampaikan pesan-pesan dari pelaku politik terhadap sasaran politik. Pola komunikasi politik memiliki karakteristik tersendiri, karakteristik tersebut dapat dilihat berdasarkan kode tutur yang digunakan. (Eliya dan Zulaeha 2017 : 287).

Adanya kemajuan teknologi di era digital mempengaruhi keefektifan komunikasi politik. Di era digital ini seorang aktor politik dapat dengan mudah mengirim pesan kepada pengikutnya. Komunikasi Politik adalah komponen penting bagi Ridwan Kamil dalam memberikan pengaruh bagi para sasaran Politiknya. Komunikasi politik juga dapat membentuk citra yang ingin dibentuk. Namun hal negatif dari memberikan pengaruh yang kuat adalah timbulnya para pengikut yang terkesan fanatik, sehingga para pengikut yang terkesan fanatik ini tidak bisa berpikir lebih luas tentang tokoh yang di idolakan.

populisme adalah sebuah ideologi yang tipis, dalam melihat masyarakat populisme terbagi menjadi dua yaitu polarisasi homogen dan antagonistik,. Populisme telah membagi antara orang baik dan orang jahat. Orang baik dipersepsikan bisa membantu, menolong, dan menggunakan jabatannya untuk masyarakat. Sebaliknya orang jahat tidak berpihak pada rakyat dan menggunakan jabatannya untuk diri dan keluarganya. (Habbodin 2017:174)

isu populisme bisa menjadi strategi yang baik untuk menciptakan kedekatan langsung dengan rakyat. Seperti yang dilakukan Ridwan Kamil dalam membentuk kedekatan kepada masyarakat melalui media Instagram. 
Moses Stephen Pandu Prawira, Diah Ayu Candraningrum: Karakteristik Populisme Gubernur Jawa Barat (Ridwan Kamil) dalam Postingan Instagram 27 Mei 2018 - 27 Juni 2018

Dalam hal ini populisme menjadi strategi tersendiri dari seorang Ridwan Kamil dalam masa kampanye. Ciri-ciri populisme yang terdapat di postingan Ridwan Kamil sangat dapat terasa. Karena banyak sekali postingan-postingan Ridwan Kamil yang sesuai dengan karakteristik pemimpin populis. Walau demikian tidak setiap kasus dapat diselesaikan dengan isu populisme. Populisme dapat menjadi bumerang bagi penggunanya karena tidak setiap persoalan rakyat dapat dijawab dengan isu populisme.

\section{Simpulan}

Populisme merupakan fenomena komunikasi yang terjadi di dalam komunikasi politik. Populisme banyak digunakan oleh para pemimpin dunia untuk mendapatkan suara rakyat. Namun Populisme belum tentu dapat menjawab persoalan yang terjadi di masyarakat. Karena Populisme membutuhkan popularitas, popularitas membutuhkan citra. Populisme berpengaruh kuat terhadap elektabilitas pasangan calon politik. Populisme berdampak negatif terhadap pengaruh followers karena akan menimbulkan kesan fanatik. Ridwan Kamil dapat dikategorikan sebagai pemimpin yang populis.

Postingan Instagram Ridwan Kamil dinilai menarik, informatik untuk dinikmati dan dibaca. Pesan yang diberikan Ridwan Kamil di Instagram berisi isu-isu pembangunan yang umumnya dikaitkan dengan kepopuleran personalnya.Citra sebagai pemimpin yang modern dan inovatif adalah citra yang di tampilkan Ridwan Kamil melalui postingan Instagram.Penggunaan Instagram sebagai media untuk menciptakan citra dinilai tepat. Pengguna Instagram sebagai media untuk menciptakan citra lebih condong menargetkan anak muda.

\section{Ucapan Terima Kasih}

Dalam Kesempatan ini, peneliti ingin mengucapkan terima kasih yang sedalamdalamnya kepada Tuhan Yang Maha Esa, Ibu Diah Ayu Candraningrum S.T., M.B.A., M.Si. selaku dosen pembimbing yang selalu memberikan bimbingan, memberikan semangat, pembelajaran serta pengetahuan baru tentang praktek kehidupan sehari-hari untuk peneliti. Keluarga peneliti yakni Papi, Mami yang selalu memberikan semangat dan dukungan dalam proses penyusunan skripsi ini, dan kepada key informan Bapak Khalid Zabidi, informan pertama Bapak Ryan Marcelino, Informan kedua Bapak Richard Anthony.

\section{Daftar Pustaka}

Adian, Donny Gahral. (2016). Pengantar Fenomenologi. Depok: Koekoesan.

Agustinova, Danu Eko. (2015). Memahami Metode Penelitian Kualitatif: Teori dan Praktik . Yogyakarta: Calpulis.

Arikunto, Suharsimi. (2016). Prosedur Penelitian Suatu Pendekatan Praktik. Jakarta: Rineka Citra.

Gunawan, Imam (2013) Metode Penelitian Kualitatif. Jurnal Universitas Negri Malang. Terarsip di: http://fip.um.ac.id/wp-content/uploads/2015/12/3 Metpen- Kualitatif.pdf 
Manzilati, Asfi. (2017). Metodologi Penelitian Kualitatif: Paradigma, MetodedanAplikasi. Malang: UB Press.

Moleong, Lexy J. (2018). Metodologi Penelitian Kualitatif: Cetakan ketigapuluhdelapan. Bandung: PT Remaja Rosdakarya.

Paramita, Sinta (2014) Komunikasi Politik dan Demokrasi Etnis Tionghoa Dalam Pemilu 2014. Jurnal Prodi Ilmu Komunikasi Universitas Brawijaya Malang

Rahma, Anisa Nur Nia (2019). Pasang Surut Populisme: Satu Dekade Populisme Basyir Ahmad di Pekalongan. Yogyakarta: PolGov

Widodo. (2017). Metodologi Penelitian Populer dan Praktis. Jakarta: PT Raja Grafindo Persada. 